\title{
Whither, Malaysia? A Multicultural Country at the Crossroads
}

\author{
Christoph Marcinkowski*
}

\section{Terrorism Finally Arriving Also at Malaysia?}

Contrary to some of her neighbours, Malaysia had - until recently - not featured in the international headlines as a place known for religiously motivated acts of terrorism. This appears to have changed: since 2009, we have witnessed intrusions into churches, a development that culminated in January 2010 in attacks and burnings of houses of worship of ethnic minorities - and increasingly also of mosques - throughout the country.

Although the roots might lie much deeper, in particular the issue on the use of the word 'Allah' for 'God' by non-Muslims in Malaysia has laid bare the currently prevailing true dimensions of interethnic distrust - in spite of a final and definitive decision by its own Supreme Court which allowed that use. ${ }^{1}$

As someone who has been living in Malaysia - with brief interruptions - since 1995, and whose work at IAIS Malaysia - a think tank - is involving the study of inter-communal relations, this writer has been asked numerous times in the course of the last weeks and months to give his personal views and perceptions. What follows is thus aiming at constructive solutions and recommendations - in other words at what a 'viewpoint' and a 'think tank' should be all about.

\section{Towards Responsible Practising of Religion}

The central question - even from a strictly Islamic point of view - is how to define the correct place of religion in dealing with the issues at stake. The real confrontation is thus populism, ignorance and, at times, collective paranoia versus true and comprehensive knowledge of oneself as well as 'the Other'.

To say it in a straight manner right at the beginning: As the recent disturbances started unfortunately by (mis)using the name of Islam, there is thus an urgent need for knowledgeable, truly pious, and well-meaning people on the pulpit in the mosques, as well as of true spirituality and knowledge of the original tenets of religion. The greatest dangers (also with a wider geographical perspective in mind) for a peaceful co-existence of Islam with 'the Other' can thus be seen in what we would call the 'kidnapping'2 or 'indigenisation' of Islam - a world religion after all - by the ignorant ones. There should be no place for preachers who are pushing

* Dr Christoph Marcinkowski is Principal Research Fellow and Co-Chair of Publications at IAIS Malaysia. 
religion down to the level of parochialism. Moreover, the practising of tolerance should first start within one's own community - for instance, when dealing with dissent from within.

There can thus be no doubt then that the Malays as a whole have a responsibility towards 'their' God and mankind as a whole as to how the religion most of them claim to profess - Islam - is propagated and practised. As a matter of fact, this is due to any believer in any religion with some sort of ethical demands. To say "we are born as members of a particular race and therefore 'saved' and we don't care what 'infidels' say about us" would be against the core teachings of Islam, which is said to encourage people to be self-reflective. Everything else would be tantamount to takabbur - arrogance and false pride against God and other fellow human beings. Unfortunately, religion is seen by many of its local practitioners as a purely 'Malay matter' - some would even argue that this includes a quasi 'copyright on God' on how and in which language to address Him, our Maker - Muslims as well as non-Muslims. God, however, does not 'belong' to any particular ethnic group.

\section{True Preservation of Religious Identity versus Parochialism}

Here we cannot deal with the questions of what is a 'Malay' by definition, or whether there exists something such as a 'Malay ethnicity', whether such an ethnicity should play a role in the building of confidence and trust within a modern state that attempts to function as a unified nation or within the wider Southeast Asian setting at the beginning of the twenty-first century. ${ }^{3}$ The 'indigenisation' of the universal message of Islam, however, which is supra-national in its very core and essence, by dragging it down to an expression of rural 'identity' à la kampong would run counter to the original tenets and stipulations of Islam, not to speak of the meaning of religion in general. Islam is said to favour friendly relations with one's neighbour, encouraging trade and commerce, technological progress and research, and interethnic relations, and above all, condemns 'inbreeding' and social inactivity. Anything else then would be totally at odds with the rest of the Islamic world which saw since the seventh century the spread of that religion among many cultures and ethnicities - Arabs, Europeans, Persians, Indians...

Already back in the 1980s, Tun Mahathir Mohamad, Malaysia's then Prime Minister, made the following remarkable statement, which, in spite of the fact that he himself is a rather controversial figure, is nevertheless also relevant to the present context:

The Malays have emerged from a long period of backwardness only to be pulled in different directions by conflicting forces, some of which seek to undo whatever progress has been made and plunge the entire community back into the Dark Ages. One of the saddest 
ironies of recent times is that Islam, the faith that once made its followers progressive and powerful, is being invoked to promote retrogression which will bring in its wake weakness and eventual collapse. A force for enlightenment, it is being turned into a rationale for narrow-mindedness; an inspiration towards unity, it is being twisted into an instrument of division and destruction. Ignorance of what constitutes spirituality, and failure to see the distinction between materialism and a healthy involvement in worldly concerns, render some sections of the Malay (Muslim) community susceptible to the notion that Islam exhorts believers to turn their backs on the world. [...] Misinterpretation of Islam is only one of the many forms of confusion threatening the Malays today. The challenge is tremendous - the stake survival itself. ${ }^{4}$

On a somewhat more positive note it was reported on 22 January 2010 in the national media that Malaysia's opposition party PAS - according to their 'spiritual leader' Datuk Nik Abdul Aziz Nik Mat - was expected to invite non-Muslim leaders to attend its 56th Annual General Assembly later that year. Perhaps, this could also be a step in the right direction for the Malaysian Government in order to re-establish mutual trust. Recent signals that have come out from the UMNO-led Government are encouraging but must be continued even after things have cooled down in order to avoid recurrence.

\section{Recommendations}

In order to address then those issues and the current disruptions in Malaysia's intercommunal setting, we recommend the following:

- To strengthen its 1Malaysia nation-building agenda, the Malaysian Government needs to draw on the inclusive and Islamic (!) concept of ummat Malaysia ('Malaysian nation'), rather than on other exclusive and rather parochial projects. This would not amount to some sort of 'innovation' (bid 'ah) as often claimed by extremists, since it would be well-grounded in early Islamic practice - to wit the so-called 'Constitution of Medina', a similar 'nationbuilding' pact between Muslims and non-Muslims which declared the creation of a new ummah that included the Jews of Medina.

- The role of the media in projecting a true and more accurate picture of all constituents of Malaysian society - but also of the outside world at large needs to be reemphasised. There are also numerous non-Muslims out there, who do seek genuine and true conciliation with the Muslims.

- The very useful and crisis-proven Internal Security Act (ISA) should be applied impartially, as recently also suggested by certain Government sectors themselves; this would help to re-establish national (and international) trust 
in the Government and its law enforcement institutions; the Malaysian Government - especially the still Malay-dominated police force - needs to be perceived as impartial when it comes to disturbances of internal peace and order.

- Covert 'solidarisation' by the wider Malay Muslim public with extremists and terrorists who claim to act on behalf of Islam in- and outside the country should be avoided at all costs.

- From the legal and law-enforcement perspective, acts of rebellion (fitnah), such as the recent burnings of churches, temples, and mosques, should be treated as such and not as mere 'arson'; anti-terrorism and high treason legislation should be invoked against extremists, as those elements constitute a threat to national security. Perhaps the application of sharī ah law - usually so fervently demanded by religious extremists - should also be considered against arsonists and other terrorists if they happen to claim to be Muslims.

- The country's ethnic majority needs to be informed about the principles of tolerance that are said to be enshrined in Islam itself and that have been practised during certain episodes of its history in other parts of the Muslim world. Moreover, in order to achieve this, they need to be educated about their own non-Muslim historical and cultural heritage (Hinduism, Buddhism, etc.) in order to avoid acts of intolerance against 'the Other' which are essentially acts of insecurity and pessimism. Muslim Arabs, Persians and Turks seem to have no problems with their own pre-Islamic legacy; to put it another way: in a social setting where animism and shamanism is still widely practised and even perceived as part of religion per se there is no need to look down on 'the Other'.

- Closely connected with the previous and in line with well-established Sunnite practice, Islam in this country should be interpreted solely by the State and the Government of the day - and by no one else; those who claim to have an 'Islamic agenda' on the 'Allah issue', for instance, should let themselves be reminded that the Qur'ān (5:32-3) $)^{5}$ itself prescribes rather harsh punishments against those who 'wage war against God and His Prophet' - in today's language: those who act violently against national security. Thus there can be no place for a selective interpretation of Islam.

- Finally, non-Muslim 'targets' of recent acts of extremist terror should do their part and give the Malaysian Government and its law enforcement agencies time to act; there can be no place for tit-for-tat activities.

Ultimately, there can be no doubt that the way in which the above issues are addressed by Malaysians and their leaders will determine the direction that Malaysia is going to take at this crucial crossroad. 


\section{Notes}

1. Only as a remark at the sidelines, it should be noted here that the Qur'ān (22:40) seems to be more generous here than its supposed supporters, to wit:

[...] Did not Allah check one set of people by means of another, there would surely have been pulled down monasteries, churches, synagogues, and mosques, in which the name of Allah is commemorated in abundant measure [...] (transl. Yusuf Abdullah; emphasis added).

2. This IAIS Viewpoint expands on material which was first published in Christoph Marcinkowski, “'Kidnapping' Islam? Some Thoughts on Southern Thailand's Muslim Community Between Ethnocentrism and Constructive Conflict-Solution", Islamic Culture 78, no. 2 (2004), 79-86 (also available online at http://mis-pattani.pn.psu.ac.th/registra/grade/temp/speech/20020823/ Panel18\%5B1\%5D.doc.

3. It should be noted in this regard that the Journal of Southeast Asian Studies (JSEAS) has published a volume which contains relevant contributions on the question of 'Malay ethnicity': see Anthony Reid, "Understanding Melayu (Malay) as a Source of Diverse Modern Identities", JSEAS 32, no. 3 (October 2001), 295-313; A.B. Shamsul, "A History of an Identity, an Identity of a History: The Idea and Practice of 'Malayness' in Malaysia Reconsidered", JSEAS 32, no. 3 (October 2001), 355-66, and Leonard Y. Andaya, "The Search for the 'Origins' of Melayu”, JSEAS 32, no. 3 (October 2001), 315-30.

4. Mahathir Mohamad, The Challenge (Petaling Jaya: Pelanduk Publications, 1993, 4th printing), vii-viii (emphasis added). Conf. idem, The Malay Dilemma (Singapore and Kuala Lumpur: Times Books International, 1995, reprint), passim.

5. In the translation of Yusuf Abdullah we read:

We ordained for the Children of Israel that if any one slew a person - unless it be for murder or for spreading mischief in the land - it would be as if he slew the whole people: and if any one saved a life, it would be as if he saved the life of the whole people. Then although there came to them Our apostles with clear signs, yet, even after that, many of them continued to commit excesses in the land. The punishment of those who wage war against Allah and His Messenger, and strive with might and main for mischief through the land is: execution, or crucifixion, or the cutting off of hands and feet from opposite sides, or exile from the land: that is their disgrace in this world, and a heavy punishment is theirs in the Hereafter. (Emphasis added) 